\title{
The Effect of Food Quality and Rearing Density on the Growth and Survival of Epibenthic Juveniles of the Sea Cucumber Holothuria scabra
}

\author{
Thierry Lavitra ${ }^{1,2}$, Richard Rasolofonirina', Philippe Grosjean ${ }^{3}$, Michel Jangoux ${ }^{2,4}$ \\ and Igor Eeckhaut ${ }^{2}$ \\ ${ }^{1}$ Institut Halieutique et des Sciences Marines (IH.SM), Université de Tuléar, 601-Tuléar, Madagascar; ${ }^{2}$ Service \\ de Biologie marine, Université de Mons-Hainaut, 7000-Mons, Belgique; ${ }^{3}$ Ecologie numérique des milieux \\ aquatiques, Université de Mons-Hainaut, 7000-Mons, Belgique; ${ }^{4}$ Service de Biologie marine, Université Libre \\ de Bruxelles, 1050-Bruxelles, Belgique.
}

Keywords: Holothuria scabra, epibenthic juveniles, rearing, survival, growth

\begin{abstract}
Seven combinations of aquatic plant extracts were tested to feed juveniles of H. scabra: Thalassia hemprichii, T. hemprichii with $3 \%$ Spirulina, Sargassum latifolium, S. latifolium with 3 $\%$ Spirulina, Thalassodendron ciliatum, Syringodium isoetifolium and organic biofilm. A control test consisted in rearing epibenthic juveniles in tank without any food supply. The results showed that extracts of S. latifolium with or without Spirulina gave the best growth and high survival rates: the mean epibenthic volumes were $112+/-55 \mathrm{~mm}^{3}$ and $81+/-21 \mathrm{~mm}^{3}$ and the survival rates were 60 and $68 \%$ respectively at the end of the experiment ( 8 weeks).

Rearing densities of $150,300,450$ and 600 individuals $\mathrm{m}^{-2}$ were tested. The best survival rates (greater than $60 \%$ ) were observed in the batches with an initial density of 450 individuals $\mathrm{m}^{-2}$ or less. The best growth rate was observed with an initial rearing density of 150 individuals $\mathrm{m}^{-2}$. The study of biomass showed that the optimum level for the rearing density is $450+/-150$ juveniles $\mathrm{m}^{-2}$. When the parameters of survival, growth rate and biomass (expressed in volume) are all taken into consideration, the optimum rearing density suggested for epibenthic juveniles of $H$. scabra is between 300 and 450 individuals $\mathrm{m}^{-2}$.
\end{abstract}

\section{INTRODUCTION}

Sea cucumbers, particularly species of the families Holothuridae and Stichopodidae, are overexploited in different regions of the world (Battaglene, 1999b; Conand, 2001, 2004; Conand \& Byrne, 1993; ToralGranda, 2006). In Madagascar, the overexploitation is so intensive that it may lead to the disappearance of the holothurian resource in a short time; this is indeed true for the entire west coast of the island (Conand, 1998; Conand et al., 1997; Rasolofonirina \& Conand, 1998). Since 2000, Madagascar has been exporting an average of $820 \mathrm{t}$ of trepang (dried sea cucumber) per year (Lavitra, 2008).

Aquaculture is considered as the best solution to decrease fishing pressure and restore natural stocks of sea cucumbers (Conand, 2001; Purcell $\&$ Kirby, 2006). Since 1990, several projects have thus been developed to assess the potential of sea cucumber for small-scaled aquaculture in the Indo-Pacific Ocean where Holothuria scabra Jaeger, 1833 seems the most promising species (Battaglenne, 1999a; James, 2004; Gamboa et al., 2004, Pitt \& Duy, 2004). For that purpose, a sea cucumber mariculture project was launched in Toliara (South West of Madagascar) in 1999. The 
facility known as Aqua-Lab includes a hatchery and a grow-out farm (Jangoux et al., 2001) where the different developmental stages of $H$. scabra are now cultivated under controlled conditions.

At the Aqua-Lab hatchery, after larval metamorphosis, juveniles of $H$. scabra are firstly epibenthic (they remain on the substrate and never burrow) for six to eight weeks. They are reared in tanks without sediment until they reach 10 to $20 \mathrm{~mm}$ ( 0.3 to $1 \mathrm{~g}$ ). At this stage, they become endobenthic (burrow into the sediment during the day) and are transferred into outdoor ponds filled with sediment collected from the natural environment (seagrass beds). When juvenile H. scabra are epibenthic, their survival and growth is particularly dependent on the availability and the quality of food as well as the rearing density (Battaglene, 1999b; Battaglene et al., 1999; James, 2004; Pitt \& Duy, 2004; Agudo, 2007), therefore, several types of food and rearing density have been suggested in the literature. However, with the exception of Battaglene et al., (1999) who experimented with two different stocking densities (300 and 1,000 juveniles tank ${ }^{-1}$ ) and two feeding regimes (Algamac ${ }^{\odot}$ and Livic), none of the existing works explain how the authors monitored experiments to draw their conclusions (James, 2004; Pitt \& Duy, 2004; Agudo, 2007). The present work is the first that explains the effects of various food types and the rearing densities on epibenthic juveniles of $H$. scabra.

\section{MATERIALS AND METHODS}

Experiments were conducted in the AquaLab hatchery, based at the IH.SM site (Institut Halieutique et des Sciences Marines), University of Toliara (Madagascar), between January 2005 and April 2007. Mature individuals of H. scabra were collected on several occasions from their natural environment (Toliara bay) and brought to the hatchery. The fertilization technique and larval rearing methods used were those described by Rasolofonirina (2004). After metamorphosis and settlement, epibenthic juveniles were transferred into tanks for experimentation. Newly settled juveniles measuring $0.5 \mathrm{~mm}$ in length attached firmly to settlement surfaces. They were collected with Pasteur pipettes and distributed onto polyester plates, each with a surface area of $0.05 \mathrm{~m}^{2}$. The plates containing the juveniles were placed in 15 1 tanks with a surface area of $0.28 \mathrm{~m}^{2}$ oxygenated by means of an air compressor. With the insert polyester plate included, the surface area in each experimental tank was then $0.33 \mathrm{~m}^{2}$. Sea water was changed every two days and the whole tank surface and the plate were cleaned every two weeks. All experiments were conducted in the hatchery at a temperature range of $28-32{ }^{\circ} \mathrm{C}$. The number of the juveniles tested varied depending on the experiments (see below).

\section{Effect of food quality}

The same experiment was carried out at different periods of the year (Trials 1 and 2, January 2005; trial 3, October 2005; trials 4 and 5, January 2006) and an initial density of 150 individuals $\mathrm{m}^{-2}$ was used (50 juveniles per tank). During each eightweek trial, seven batches of juveniles were reared with seven different types of food and their survival and growth rates compared. The food types tested were: $(i)$ an extract of Thalassia hemprichii, a seagrass species, (ii) an extract of T. hemprichii with $3 \%$ Spirulina, source of protein, (iii) an extract of Thalassodendron ciliatum, a second seagrass species, (iv) an extract of Syringodium isoetifolium, a third seagrass species, (v) an extract of Sargassum latifolium, a brown alga, (vi) an extract of $S$. latifolium with $3 \%$ Spirulina and (vii) an organic biofilm. The control test in each trial consisted of observing the survival and growth of epibenthic juveniles in filtered seawater without any food supply. In total, 400 individuals were used for every trial ( 8 batches with 50 individuals each).

To prepare extracts, newly collected brown algae and seagrass were cut into small pieces, grounded into a fine paste and filtered on a 80 $\mu \mathrm{m}$ mesh sieves. The extracts were collected, conserved at $4{ }^{\circ} \mathrm{C}$ and used as food for epibenthic juveniles of $H$. scabra. The food was given daily at the end of the afternoon at a rate of $10 \mathrm{mg} \mathrm{l}^{-1}$ (dry weight) during the first week, $15 \mathrm{mg} \mathrm{l}^{-1}$ during the second and $20 \mathrm{mg} \mathrm{l}^{-1}$ for the remaining weeks. For juveniles fed with a biofilm, the biofilm was collected by placing plates of $0.05 \mathrm{~m}^{2}$ in Aqua-Lab aquaria for two to three weeks. After this period 
of time, 2, 3 and 4 plates (equivalent to the same amount in dry weight of food extract) were scrubbed and the collected effluent was added daily into the tanks during the first, second and the remaining weeks respectively.

\section{Effect of rearing density}

This experiment was also repeated five times at different periods of the year (November 2006 for the two first trials and March 2007 for the three remaining trials). Each trial lasted eight weeks. Four initial rearing densities, 150, 300, 450 and 600 individuals $\mathrm{m}^{-2}$ (corresponding to 50, 100, 150 and 200 juveniles per tank respectively) were tested and the growth and survival of epibenthic juveniles between batches were compared. For each trial, a total number of 500 individuals were used. Epibenthic Juveniles were fed with the extract of Sargassum with $3 \%$ Spirulina. The food was given every two days at the end of the afternoon with $10,20,30$ and $40 \mathrm{mg} \mathrm{l}^{-1}$ of extracts (dry weight) in tanks whith densities of $150,300,450$ and 600 individuals $\mathrm{m}^{-2}$ respectively.

Data analysis

Epibenthic juveniles extended and retracted readily which introduced bias to the measurements. Consequently, the volume of juveniles was calculated so that both length and width were taken in account. The juvenile shape was assumed to be a cylinder and the global volume was calculated with the formula: $\pi r^{2} L$ where $r$ represents the radius and $L$ the length. Measurements were done using an optical microscope and carried out at the beginning of the experiments and every two weeks afterwards. Juveniles were counted every two weeks to determine the survival rate.

Homogeneity of variance and normality were assessed using Levene's and KolmogorovSmirnov's tests, respectively. As trials were conducted at a different period of time, 2-factor ANOVA test was carried out to compare the average volume of juveniles and then, an LSD test was selected as post-hoc test for comparison of means. Due to repeated measurements, a Friedman test was used to analyse non-independent data followed by the Behrens-Fisher test for comparison of means. Statistic analyses were performed by using SYSTAT v9, SPSS v13 and R.2.6.1 software.

\section{RESULTS}

Effect of food on survival and growth of hatcheryreared epibenthic $H$. scabra juveniles

\section{Survival}

The survival rates of epibenthic juveniles fed over the eight week trial period varied from 34 to 66 $\%$ (50 individuals per tank at the beginning of the experiment; 17 to 33 individuals per tank towards the end) depending on the food tested while only 7 $\%$ of juveniles were alive in the control test (without any artificial food supply) (Fig. 1). The results clearly demonstrate that both food availability and food types affects the survival of epibenthic juveniles of $H$. scabra ( $\mathrm{p}=0.0018)$, however no difference was observed between seagrasses and alga (Fig. 1).

\section{Growth}

As batches fed with $T$. hemprichii (with or without Spirulina), S. latifolium (with or without Spirulina) and $T$. ciliatum increased survival rates (more than $50 \%$ at the end of the experiment), they were considered in subsequent experiments. At the beginning, epibenthic juveniles were an average size (volume) of $0.034 \mathrm{~mm}^{3}$. After eight weeks of rearing, a significant difference was observed in size ( $p=0.0066)$ depending on the type of food tested. For the five food types considered, the extract of S. latifolium with and without Spirulina gave the best growth rate. The average volumes of epibenthic juveniles fed with those two types of food were $112+/-55 \mathrm{~mm}^{3}$ and $81+/-21 \mathrm{~mm}^{3}$ respectively at the end of the rearing period (Fig. 2). Extracts of seagrasses $T$. ciliatum and T. hemprichii with or without Spirulina gave lower growth rates with juveniles at the end of the experiment showing respective sizes (volumes) of 48,39 and $25 \mathrm{~mm}^{3}$ (Fig. 2).

Characteristics of the best rearing regime (juveniles fed with S. latifolium with $3 \%$ Spirulina) are presented in table 1 . On average, $34 \%$ of epibenthic juveniles died during the rearing period (8 weeks). However, mortality rates were not the same during the entire rearing period, rather mortality was more important during the two first 


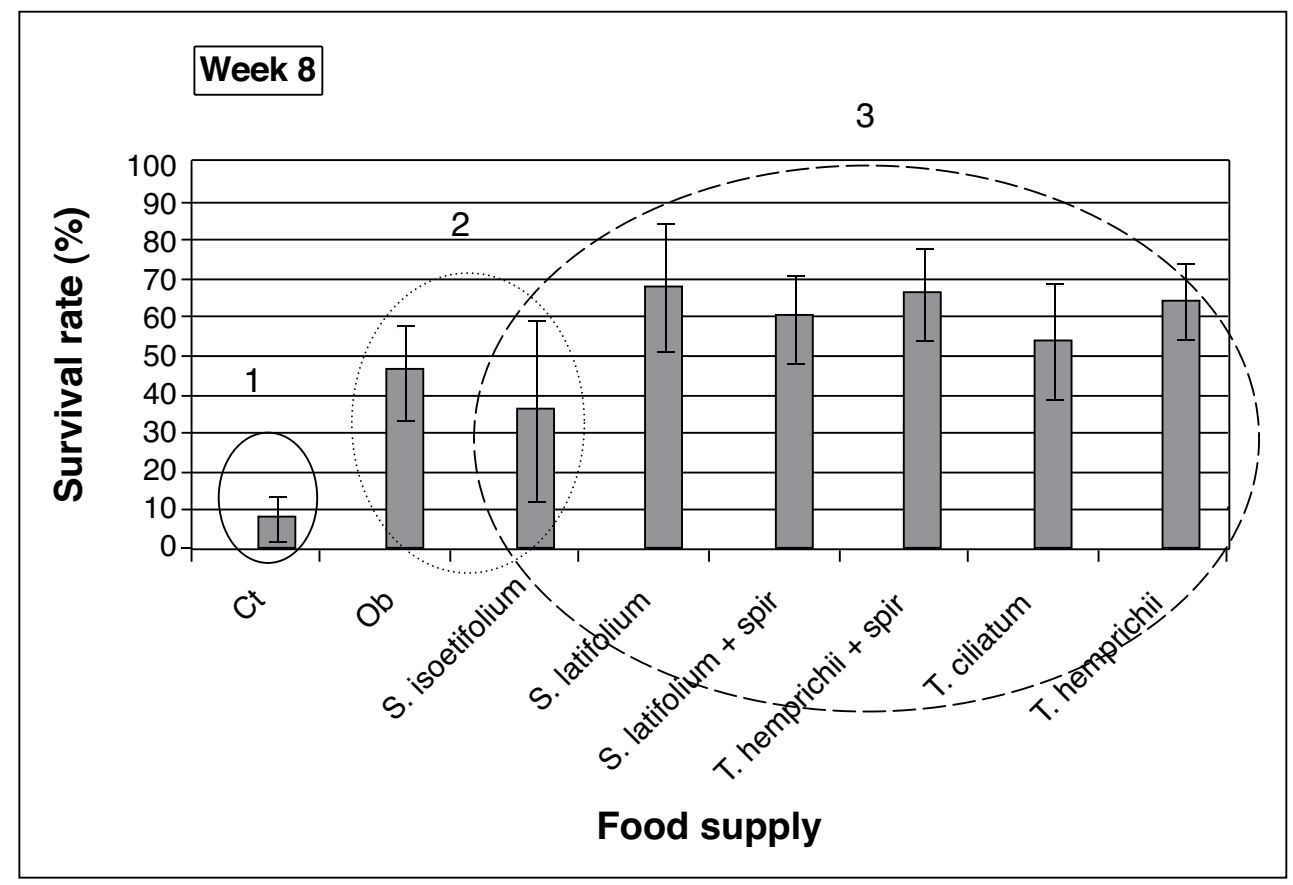

Fig. 1. Variation in the average survival rate of batches of epibenthic juveniles of $\boldsymbol{H}$. scabra depending on food supply after eight weeks of rearing. Vertical lines represent standard deviation. Batches inside circle do not show any significant differences after statistical analysis. Abbreviations: $\mathrm{Ct}$ : control test; Ob: organic biofilm, S. isoetifolium: Syringodium isoetifolium; S. latifolium: Sargassum latifolium; S. latifolium + spir: Sargassum latifolium with $3 \%$ Spirulina; T. hemprichii + spir: Thalassia hemprichii with $3 \%$ Spirulina; T. ciliatum: Thalassodendron ciliatum; T. hemprichii: Thalassia hemprichii



Fig. 2. Growth of epibenthic juveniles of $\mathrm{H}$. scabra depending on the food supply. Vertical lines represent standard deviation. Batches inside of same circle do not show any significant differences 
Table1: Evolution of the mortality and growth of epibenthic juveniles of $H$. scabra (juveniles fed with S. latifolium with $3 \%$ Spirulina)

\begin{tabular}{ccccc}
\hline $\begin{array}{c}\text { Rearing time } \\
\text { (week) }\end{array}$ & $\begin{array}{c}\text { sizes of juveniles } \\
\left(\mathbf{m m}^{\mathbf{3}}\right)\end{array}$ & Number of individuals & $\begin{array}{c}\text { Mortality } \\
(\boldsymbol{\%})\end{array}$ & $\begin{array}{c}\text { Growth rate } \\
\left(\mathbf{m m}^{\mathbf{3}} \mathbf{j}^{\mathbf{1}}\right)\end{array}$ \\
\hline $0-2$ & $0.03-1.5$ & $50-40$ & 20 & 0.11 \\
$2-4$ & $1.5-29$ & $40-36$ & 8 & 1.79 \\
$4-6$ & $29-92$ & $36-34$ & 4 & 3.55 \\
$6-8$ & $92-112$ & $34-33$ & 2 & 1.38 \\
\hline
\end{tabular}

weeks. Overall, the mortality rates observed were $20,8,4$ and $2 \%$ during the second, fourth, sixth and eighth week of rearing, respectively. The growth rate also varied over time. It was relatively slow during the two first weeks, it increased and reached a maximum between the fourth and sixth week and then decreased again (Table 1).

Effect of rearing density on survival, growth and biomass (expressed in volume) of epibenthic juveniles of $H$. scabra.

Overall, the growth and the survival of $H$. scabra epibenthic juveniles were inversely proportional to the rearing density: the higher the settling density, the lower the survival and growth rates. The relationships between "survival vs. rearing density" and "growth vs. rearing density" were both linear and statistically significant $(\mathrm{p}=$ 0.0000) (Fig. 3).

\section{Survival}

Average survival rates (five trials) of epibenthic juveniles of $H$. scabra reared at four different densities are presented in figure 4. After eight weeks of rearing, survival was between 54 and 72 $\%$ depending on to the rearing density $(\mathrm{p}=0.0030)$. The best survival rates (greater than $60 \%$ ) were observed in the batches with an initial density of 450 individuals $\mathrm{m}^{-2}$ or less: in tanks with 150,300 and 450 individuals $\mathrm{m}^{-2}$ survival rates were of 72 , 65 and $61 \%$ respectively. The effect of density on the survival of epibenthic juveniles appeared from the second week of rearing $(\mathrm{p}=0.0210)$ and was clearly observed for densities of 150 and 600 individuals $\mathrm{m}^{-2}$. Differences between the average survival rates become greater over time $(\mathrm{p}=0.0170$ at the fourth week and $\mathrm{p}=0.0040$ at the sixth week of rearing).

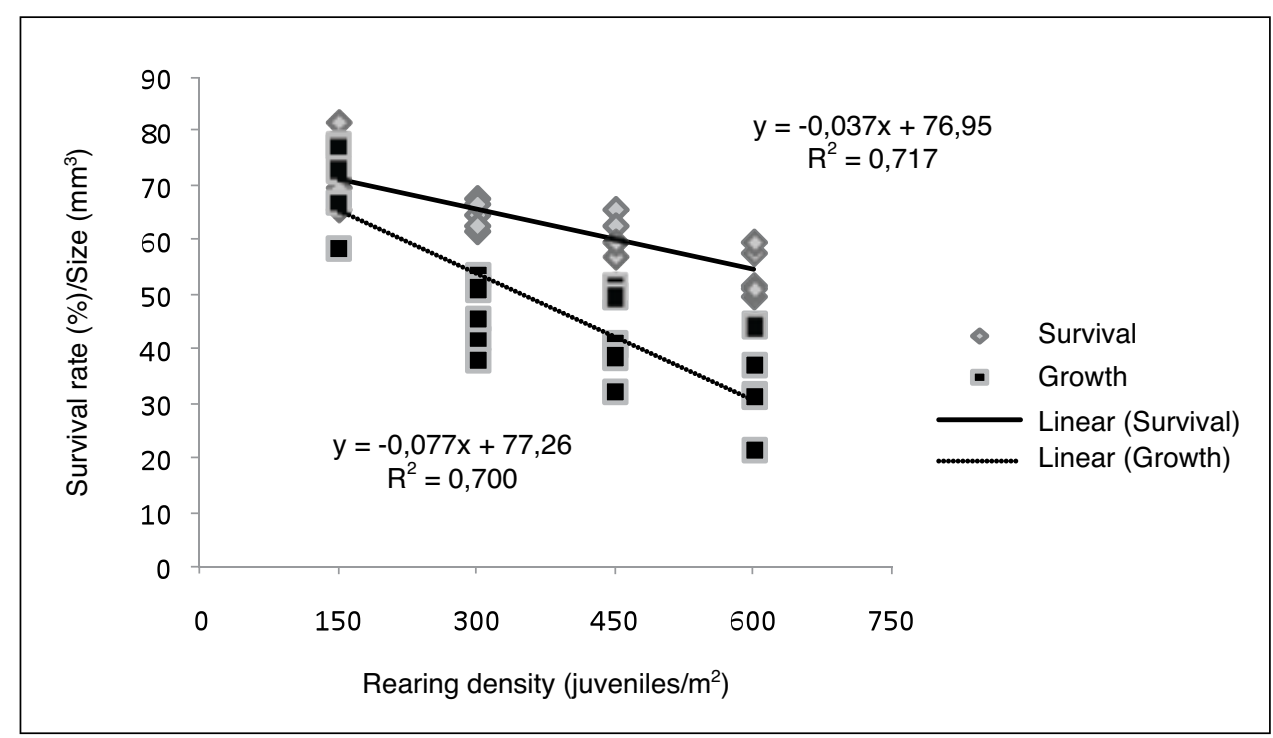

Fig. 3. Relationship between rearing density (individuals $\mathrm{m}^{-2}$ ) and survival rate $(\%)$ and rearing density and growth $\left(\mathbf{m m}^{3}\right)$ in epibenthic juveniles of $H$. scabra after eight weeks of rearing $(\mathbf{p}=\mathbf{0 . 0 0 0 0})$ 




Fig. 4. Variation in the average survival rate of batches of epibenthic juveniles of $H$. scabra depending on the rearing density during eight weeks of rearing. Vertical lines represent standard deviation. Vertical arrows represent the significant difference between two batches. Batches inside same bracket do not present any significant difference

\section{Growth}

The average size of epibenthic juveniles of $H$. scabra obtained from 4 different rearing densities (five trials) are presented in figure 5. After eight weeks of rearing, juveniles showed different sizes ( $\mathrm{p}=0.0018$ ) depending on the densities tested. The best growth rate was observed with an initial rearing density of 150 individuals $\mathrm{m}^{-2}$ where juveniles had a mean volume of $73 \mathrm{~mm}^{3}$ towards the end of the experiment. Densities of 300,450 and 600 individuals $\mathrm{m}^{-2}$ resulted in lower growth rate and juveniles at the end of the experiment showed respective sizes of 46,41 and $32 \mathrm{~mm}^{3}$. During the two first weeks of rearing, the rearing density did not affect the growth of juveniles ( $p$ $=0.2700)$. It starts to have its own effect at the fourth $(\mathrm{p}=0.0140)$ and sixth week $(\mathrm{p}=0.0290)$, however the difference between rearing batches is only significant between densities of 150 and 600 individuals $\mathrm{m}^{-2}$.

\section{Effect of density on biomass (expressed in volume)}

Figure 6 shows the biomass recorded after eight weeks of rearing for the different densities tested by feeding epibenthic juveniles of $H$. scabra with an extract of S. latifolium with 3\% Spirulina. The results demonstrated that the rearing density does affect the biomass of epibenthic juveniles ( $p=$ $0.005)$. The rearing density of 450 individuals $\mathrm{m}^{-2}$ gave better yields than 150 individuals $\mathrm{m}^{-2}$ (Fig. 6).

\section{DISCUSSION AND CONCLUSION}

In aquaculture today, several types of food are used to feed post-metamorphic sea cucumber juveniles (Battaglene, 1999a; Liu et al., 2004; James, 2004). The majority of authors suggested that the addition or the use of Sargassum extracts always produced better yields (James et al., 1994; James, 1999; James, 2004; Battaglene, 1999a; Liu et al., 2004; Rasolofonirina, 2004). Our results also showed the importance of Sargassum latifolium extracts to feed epibenthic juveniles of $H$. scabra. This brown alga is easily available from the wild in the Toliara region. As it has never been used or exploited by local communities, and is very inexpensive. Another advantage of Sargassum is that it can be easily dried and stored to be used during the winter season (especially during June, July and August where there is no Sargassum in the marine environment. It should be noted that, in small-scale aquaculture operations, this dependence 




Fig. 5. Growth of epibenthic juveniles of $\boldsymbol{H}$. scabra depending on rearing density. Vertical lines represent standard deviation. Vertical arrows indicate the presence of significant difference between two batches. Batches inside the same circle do not show any significant difference



Fig. 6. Biomass (expressed in $\mathrm{mm}^{3} \mathrm{~m}^{-2}$ ) produced for each density tested. Vertical lines represent standard deviation; vertical arrows represent a significant difference between two batches. $D$ 150, 300, 450 and 600 represent the number of juveniles per $\mathrm{m}^{2}$ tested for the experience

on Sargassum is potentially viable, however, at an industrial level there is a potential risk of overexploitation of this brown algae. In the long term, further research should be conducted to identify an appropriate manufactured diet to make this activity economically and environmentally sustainable.
The addition of other types of food such as yeast, fish meal and sea kelp powder with the extract of Sargassum would also be useful (Liu et al., 2004). The use of dry powder Spirulina platensis (micro algae with over $60 \%$ protein content) is often the most suggested protein source to complement the main diet in sea cucumbers (Liu et al., 2004; Pitt 
\& Duy, 2004; Rasolofonirina, 2004). Although our study shows that the addition of Spirulina in the food of epibenthic juveniles of $H$. scabra promotes their growth, there was no statistical difference with Sargassum used alone. The high cost of Spirulina in Madagascar (56 euros per kilo) renders its use too expensive to use in industrial scale production, however it demonstrates that the inclusion of a protein source in sea cucumber food may be valuable.

The present study showed that rearing density has an influence on the growth and survival of epibenthic juveniles of $H$. scabra: the higher the rearing density, the lower the survival and the growth rate. The optimum rearing density that we suggest for epibenthic juveniles of $H$. scabra is between 300 and 450 individuals $\mathrm{m}^{-2}$ where they have both the best survival rate and biomass. Whilst juveniles reared at 150 individuals $\mathrm{m}^{-2}$ demonstrated the best growth this biomass is too low that this density cannot be seriously considered in sea cucumber aquaculture. At 600 individuals $\mathrm{m}^{-2}$ the survival rate is too low. The same trend was also observed by James et al. (1994) who proposed the optimum rearing density between 200 and 500 individuals $\mathrm{m}^{-2}$ for the same species (James et al., 1994; James, 2004) while Agudo suggested a rearing density much higher, between 500 and 700 individuals $\mathrm{m}^{-2}$ (Agudo, 2007).

In $H$. scabra farming, epibenthic juveniles of the same population do not grow at the same rate which explains the high standard deviations during measurements in the present study, as also noted by others (Pitt \& Duy, 2004; Battaglene et al., 1999; and Rasolofonirina, 2004). The best growth during the present study was $112 \mathrm{~mm}^{3}$ (about 13 $\mathrm{mm}$ long) after eight weeks. Other available data varies according to another: $13 \mathrm{~mm}$ (3 to $41 \mathrm{~mm}$ ) within one month (Battaglene, 1999a; Battaglene et al., 1999), more than $20 \mathrm{~mm}$ within two months (James, 1999; James, 2004), $11 \mathrm{~mm}$ in one month (Rasolofonirina, 2004) and between 10 and 20 $\mathrm{mm}$ in one month (Agudo, 2007). In a hatchery in general, the average growth rate is between 1 and $15 \mathrm{~mm}$ month $^{-1}$ depending on the initial size of the juveniles and the duration of the rearing (Rasolofonirina, 2004).
Survival of epibenthic juveniles of $H$. scabra is directly influenced by the type of food, the rearing density (James, 1994, 1996, 2004; Pitt \& Duy, 2004, Rasolofonirina, 2004,Agudo, 2007; present work) and the temperature (Rasolofonirina, 2004). The survival rates recorded during the present study were 34 to $66 \%$ depending on the types of food, and 54 to $72 \%$ depending on the rearing density. Battaglene (1999a) obtained a survival rate of 34 $\%$ after one month of rearing (on plates, fed with bacterial and diatoms film, density unknown). Rasolofonirina (2004) showed that survival rates varied between 41 and $75 \%$ depending on the temperature. In the present study it was noted that the highest mortality occurred during the first two weeks of rearing, when juveniles are less than $5 \mathrm{~mm}$ long. The beginning of the postmetamorphic stage is thus a critical period in the rearing of $H$. scabra juveniles.

In conclusion, the present experiments suggest that $(i)$ the optimization of survival and growth of epibenthic juveniles of $H$. scabra requires the use of a particular food, (ii) the recommended food is the extract of brown algae $S$. latifolium, (iii) the optimal rearing density is between 300 and 450 individuals $\mathrm{m}^{-2}$. In addition, the experiment shows the positive effect of the addition of a protein source to feed $H$. scabra juveniles.

Acknowledgements-This work was successfully achieved by the financial support of CUD (Commission Universitaire au Développement) of the French community of Belgium within the framework of the Holothuriculture PIC Project in Madagascar. We gratefully thank Jean Marc OUIN for his technical assistance. Special thanks to Pascal Manohitsara, Joelson Ralainirina, Nicolas Fohy, Willy A. N. Veriza and Gaëtan Tsiresy for their help at the laboratory. Sincere thanks must also be given to Georgie Robinson for helping the authors improve the English edition of the paper.

\section{REFERENCES}

Agudo, N. (2007). Sandfish hatchery techniques. The WorldFish Center, Secretariat of the Pacific Community and Australian Centre for International Agricultural Research. CPS, Nouméa, Nouvelle Calédonie. 44p. 
Battaglene, S.C. (1999a). Culture of Tropical sea Cucumber for stock Restoration and Enhancement. Naga, the ICLARM Quartely (Vol. 22, No. 4) $11 \mathrm{p}$.

Battaglene, S.C. (1999b). Progress in the production of tropical sea cucumbers Holothuria scabra and Holothuria fuscogilva for stock enhancement. SPC, Bêche-de-mer Bulletin 12: 32.

Battaglene, S. C., Seymour J. E. \&, Ramofafia C. (1999). Survival and growth of cultured juvenile sea cucumbers, Holothuria scabra. Aquaculture 178: $293-322$.

Conand, C. (1998). Overexploitation in the present world sea cucumber fisheries and perspectives in mariculture. p. 449-454. In: Mooi, R. \& Telford, M. (eds). Echinoderms: San Francisco. Rotterdam; A.A. Balkema Press.

Conand, C. (2001). Overview of sea cucumbers fisheries over the last decade-What possibilities for a durable management ?.p .339-344. In: Barker, M. (eds) Echinoderms 2000. Proceedings of the 10th International Conference, Dunedin, Lisse: Swets and Zeitlinger.

Conand, C. (2004). Present status of world sea cucumber resources and utilization: An international overview. p. 13-23. In: Lovatelli, A., Conand, C., Purcell, S., Uthicke, S., Hamel, J. F., \& Mercier, A. (eds). Advances in sea cucumber aquaculture and management. Fisheries Technical Paper No. 463. FAO, Rome.

Conand, C. \& Byrne, M. (1993). A review of recent developments in the world sea cucumber fisheries. Marine Fisheries Review 55: 1-13.

Conand, C., Galet-Lalande, N., Randriamiarana, H., Razafintseheno G. \& De San, M. (1997). Sea cucumber in Madagascar: Difficulties in the fishery and sustainable management. SPC, Bêche-de-mer Bulletin 9: 4-5.

Gamboa, R., Gomez., A. L. \& Nievales, M. F. (2004). The status of sea cucumber fishery and mariculture in the Philippines. p. 69-78. In: Lovatelli, A., Conand, C., Purcell, S., Uthicke, S., Hamel, J. F. \& Mercier, A. (eds) Advances in sea cucumber aquaculture and management. Fisheries Technical Paper No. 463. FAO, Rome.

James, D. B. (1994). A review of the hatchery and culture practices in Japan and China with special reference to possibilities of culturing holothurians in India. Central Marine Fisheries Research Institute Bulletin 46: 63-65.

James, D. B. (1996). Culture of sea-cucumber. Central Marine Fisheries Research Institute Bulletin 48: 120-126.

James, D. B. (1999). Hatchery and Culture Technology for the sea Cucumber, Holothuria scabra Jaeger, in India. Naga, The ICLARM Quart. 22 (4): 12-18.
James, D. B (2004). Captive breeding of the sea cucumber, Holothuria scabra, from India. p. 385-395. In: Lovatelli, A., Conand, C., Purcell, S., Uthicke, S., Hamel, J. F. \& Mercier, A. (eds) Advances in sea cucumber aquaculture and management. Fisheries Technical Paper No. 463. FAO, Rome.

James, D. B., Gandhi, A. D., Palaniswamy, N \& Rodrigo, J. X. (1994). Hatchery techniques and culture of the sea cucumber Holothuria scabra. CMFRI, Special publication 57, Cochin, India.

Jangoux, M., Rasoloforinina, R., Vaitilingon, D., Ouin, J. M., Seghers, G., Mara, E. \& Conand, C. (2001). A sea cucumber hatchery and mariculture project in Tuléar, Madagascar. SPC, Bêche-de-mer Bulletin 14: $2-5$.

Lavitra, T. (2008). Caractérisation, contrôle et optimalisation des processus impliqués dans le développement post-métamorphique de l'holothurie comestible Holothuria scabra (Jaeger, 1833) (Holothuroidea : Echinodermata) [Thèse], Université de Mons-Hainaut, Belgique. 166p.

Liu, X., Zhu, G., Zhao, Q., Wang, L. \& Gu, B. (2004). Studies on hatchery techniques of sea cucumber, Apostichopus japonicus. p. 287-295. In: Lovatelli, A., Conand, C., Purcell, S., Uthicke, S., Hamel, J. F. \& Mercier, A. (eds) Advances in sea cucumber aquaculture and management. Fisheries Technical Paper No. 463. FAO, Rome.

Pitt, R. \& Duy, N. D. Q. (2004). Breeding and rearing of the sea cucumber Holothuria scabra in Viet Nam. p. 333-346. In: Lovatelli, A., Conand, C., Purcell, S., Uthicke, S., Hamel, J. F. \& Mercier, A. (eds) Advances in sea cucumber aquaculture and management. Fisheries Technical Paper No. 463. FAO, Rome.

Purcell, S. W. \& Kirby, D. S. (2006). Restocking the sea cucumber Holothuria scabra: Sizing no-take zones through individual-based movement modeling. Fisheries Research 80: 53-61.

Rasolofonirina, R. (2004). Reproduction et développement de l'holothurie comestible Holothuria scabra (Jaeger 1833), Holothuroidea: Echinodermata [Thèse], Université Libre de Bruxelles.175 p.

Rasolofonirina, R. \& Conand, C. (1998). Sea cucumber exploitation in the Tuléar region of south-oust Madagascar. SPC, Bêche-de-mer Bulletin 10: 10-14.

Toral-Granda, M. V. (2006). Situation biologique et commerciale des concombres de mer des familles holothuriidae et stichopodidae. In: convention sur le commerce international des espèces de faune et de flore sauvages menacées d'extinction. 20th session du Comité pour les animaux Lima (Pérou), 7 - 13 juillet 2006 Partie: CONCOMBRES DE MER. 
